\title{
Lab on a chip automates in vitro cell culturing
}

Perozziello, Gerardo; Møllenbach, Jacob; Laursen, Steen; Fabrizio, Enzo di; Gernaey, Krist; Krühne, Ulrich

Publication date:

2011

Document Version

Publisher's PDF, also known as Version of record

Link back to DTU Orbit

Citation $(A P A)$ :

Perozziello, G., Møllenbach, J., Laursen, S., Fabrizio, E. D., Gernaey, K., \& Krühne, U. (2011). Lab on a chip automates in vitro cell culturing. Poster session presented at 37th International Conference on Micro and Nano Engineering, Berlin, Germany.

\section{General rights}

Copyright and moral rights for the publications made accessible in the public portal are retained by the authors and/or other copyright owners and it is a condition of accessing publications that users recognise and abide by the legal requirements associated with these rights.

- Users may download and print one copy of any publication from the public portal for the purpose of private study or research.

- You may not further distribute the material or use it for any profit-making activity or commercial gain

- You may freely distribute the URL identifying the publication in the public portal

If you believe that this document breaches copyright please contact us providing details, and we will remove access to the work immediately and investigate your claim 


\section{Lab on a chip automates in vitro cell culturing}

Gerardo Perozziello $^{b}$, Jacob Møllenbach ${ }^{d}$, Steen Laursend, Enzo di Fabriziob,c, Krist Gernaeya and Ulrich Krühne

a Dept. of Chemical and Biochemical Engineering , Technical University of Denmark, Søltofts Plads, Building 227, DK-2800 Kgs. Lyngby, Denmark 'BioNEM (Bio Nano Engineering and Technology for Medicine) lab, Universita' Magna Graecia" of Catanzaro , Germaneto, 88100 Catanzaro, Italy

${ }^{c}$ Nanostructure department, Italian Institute if Technology, Via Morego 30, 16163 Genova, Italy

d Smart Biosystems ApS, Hvildkildevej 48, DK-2400 Copenhagen NW, Denmark

\section{Motivation}

Recent advances of automated cell culturing are combining microelectronics, micromechanics, micro-optics, communication technologies, microfluidics and assembly technology, which has lead to a number of miniaturized devices [1-3]. Many scientific publications can be found in which integrated complicated systems are studied, while in hospitals or in fertility clinics the procedures are still predominantly based on Petri dishes.

\section{Description}

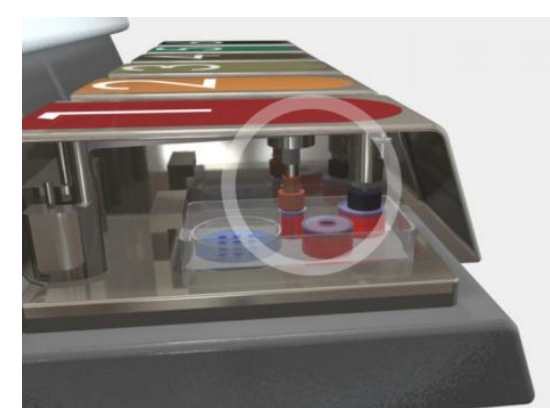

Figure 1. Side view of the IVFLAB6

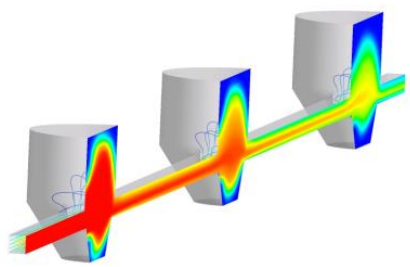

Figure 3. CFD simulation analysis of new media distribution in the IVFChip cell compartments after $10 \mathrm{~s}$.
* Fully automated culturing of six single chips

*Flow rate up to $20 \mu$ l per hour

* Can handle 2 media

* T and pH control and logging

* Undisturbed bio-mimetic environment

* Low shear stress

* Cont. metabolic waste removal

* Minute amounts of samples $(14 \mu \mathrm{l})$ for $\mathrm{pH}$

* Evaporation control by surface covering mineral oil

* Environmental control of 5 or $6 \% \mathrm{CO}_{2}$
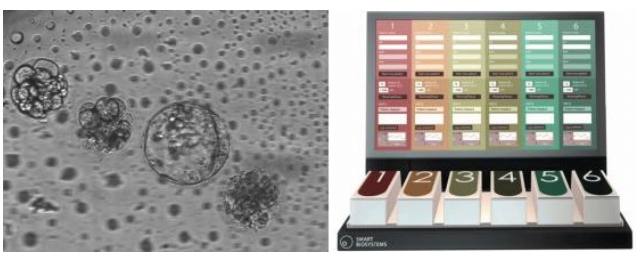

Figure 4. A photo of cultured embryo cells (left) and the integrated IVFLAB6 for microfluidic culture system (right).

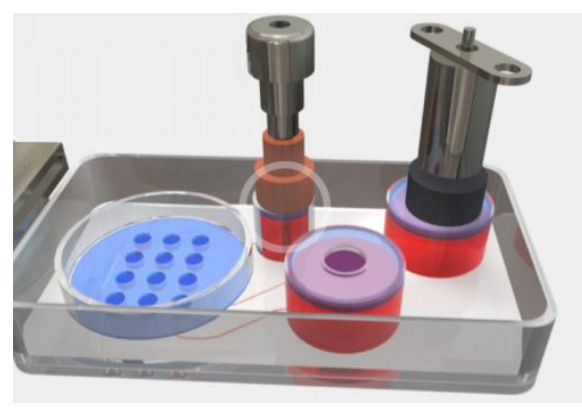

Figure 2. Valve for fluidic control and sampling compartment for $\mathrm{pH}$ measurements

One of the key features is the novel way of controlling the microfluidic distribution of media by using a combination of hydrostatic pressure and opening and closing valves on the top of the medium reservoirs (Figure 2). In this way a very gentle flow (Figure 3 ) is generated and the medium is not in contact with any other surfaces apart from the material from which the IVFChip is fabricated. This is highly important, especially with respect to regulatory restrictions.

\section{Results}

The temperature and $\mathrm{pH}$ values can be found in a cultivation at physiological levels.

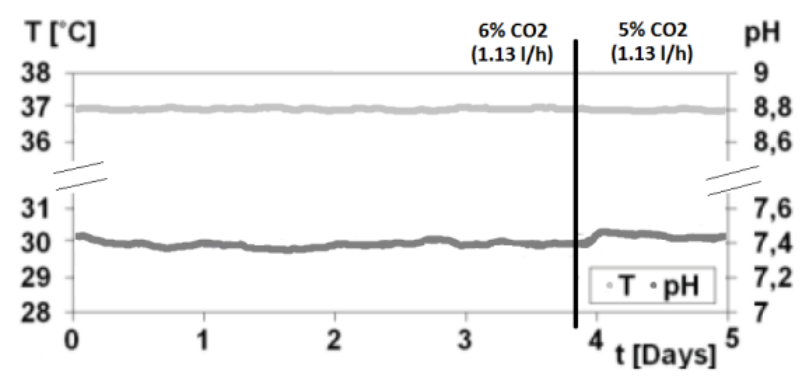

Figure 5. $\mathrm{pH}$ and temperature measurements for a period of 5 days with change the percentage of the gas.
An externally performed cytotoxicity test has been successfully demonstrating that the IVFChip is reaching comparable performance with assay control experiments (shown in Figure 6).

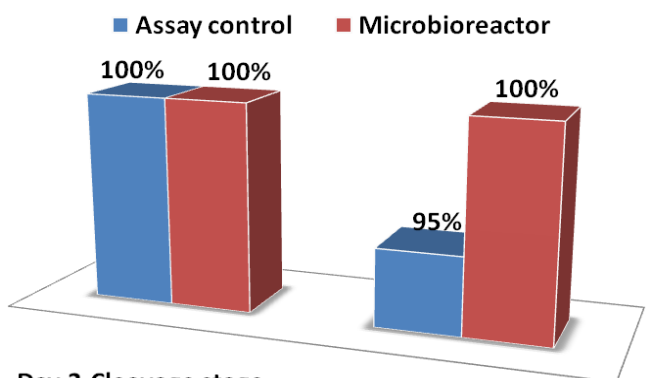

Day 2,Cleavage stage

Figure 6. Cytotoxicity tests
Day 6,Blastocyst stage

\section{Conclusions}

The described system is an efficient compromise between the demands and requests from a very conservative clinical working and research require-ments and the advances of microfluidic technology available at high technology research environments.

\section{Acknowledgments}

This work was partially supported by the European Project "SMD", proposal no. CP-FP 229375-2 of the call FP7-NMP-2800-SMALL-2 and the project FIRB " Rete Nazionale di Ricerca sulle Nanoscienze ItalNanoNet” (cod. RBPR05JH2P_010, CUP B41J09000110005)

\section{References}

[1] Gerardo Perozziello, Giuseppina Simone, Patrizio Candeloro, Francesco Gentile,Natalia Malara, Rosanna Larocca, Marialaura Coluccio, Salvatore Andrea Pullano, Luca Tirinato, Oliver Geschke and Enzo Di Fabrizio, Micro and Nanosystems, 2, (2010) 227-238. 